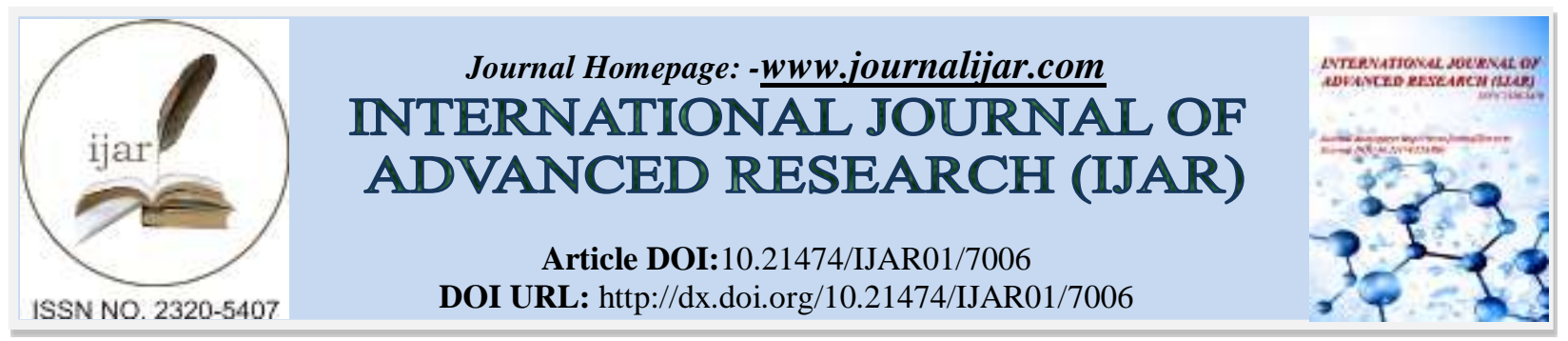

RESEARCH ARTICLE

\title{
ACCOUNTING OF PEACE: GREEN MOVEMENT IN INDUSTRY 4.0 (NECESSITY OF DECONSTRUCTION?)
}

Luky Patricia Widianingsih.

Accounting Study Program, Universitas Pelita Harapan Surabaya, Indonesia.

\section{Manuscript Info}

Manuscript History

Received: 01 March 2018

Final Accepted: 03 April 2018

Published: May 2018

\begin{abstract}
This paper provides a discussion of how Industry 4.0 supports the purpose of the green movement brought by the accounting of peace philosophy. The meaning of accounting has evolved over time. Accounting is not merely a tool to gain profit and wealth, but it must also take a role in bringing goodness to the place and the environment in which it exists. Accounting that thinks about balanced with the ecosystem, concerned with its environment, contributes to the highest achievement of wellbeing with fellow human beings, other species of living creatures and the universe. Some of the difficulties faced related to the poor quality of environmental data can be minimized by the presence of technological advances brought by the Industrial Revolution 4.0. Improvements in the environmental data quality which real-time and integrated, of course, give the potential for their use in decision making. Accounting researcher in green movement should be "deconstruction researcher". It means that: they change the human mind and understanding of "text" in environmental disclosure. They bring out new insights that were previously unthinkable. They attempt to shake up dominant and established thinking logocentrisms. So, their work not only as a symbolic but also substantive. These issues presented in this paper have implications for academics, practitioners or corporate management and policymakers.
\end{abstract}

Copy Right, IJAR, 2018,. All rights reserved.

\section{Introduction:-}

Given the emergence of the concept and the need for accounting is not separated from the long history behind the development of its thinking. Accounting can be said to have been present in conditions of war. The war economy itself is understood as a set of special economic measures undertaken to sustain proper production, commodity movements, and distribution. The overall purpose of that at the time was to meet the needs of arms and food for soldiers and people in wartime (Diaconu, 2017). From this background then the attention to how the idea of funding, loans, and taxes then emerged. The economy is aimed at war, a victory for one side, the strongest of course. It also affects accounting thinking, where all is only for the interests of capital owners, do not need to pay attention to other human resources, let alone the environment. Natural resources seem like something that can be freely taken. Accounting and thought inside are still designed for war. Accounting once stood based on a war-based economic system at that time.

Corresponding Author:- Luky Patricia Widianingsih .

Address:- Accounting Study Program, Universitas Pelita Harapan Surabaya, Indonesia. 
In the development and progress of the world today, the background of thought in history certainly cannot be brought again. Economics not only aims for the welfare of a handful of people, but for the common interest of a group or community or country. The function of accounting not only as an accountability to the owner of capital, but accounting must also successfully accountable business operations to the interests of many people, including social and environmental. The development of the industrial is undeniable to give consequences to the environment where the industry grows and develops. After all, the environment is both natural and social that gives a place for the industry to operate. Natural resources such as land, water, air, and social life that people around the industry also feel the impact of the existence of the business. Companies that realize that their existence cannot be separated from the natural and social environment will run its business by promoting principles that are economically profitable but also environmentally and socially have sustainability. Accounting ideally more reconciled to the environment. Some ideas of thought have appeared to respond to this new accounting concept. From environmental accounting terminology, green accounting, carbon accounting, carbon economics, as well as sustainability reporting concepts and integrated reporting, all have characteristics that are beginning to take account of the environment in accounting reporting. Business cannot run if only based solely on profit, but business must also be acceptable environmentally.

The world has entered the fourth industrial revolution, known as Industry 4.0. Industries hasten themselves to adapt to these demands and progress, as well as accounting that is expected to better seize the opportunities in this new era to maximize the function and usefulness of its information to stakeholders. The Government of Indonesia is committed to improving Indonesia's competitiveness position from 41st to 39th place of the world from 138 countries recorded in the Global Competitiveness Report 2016-2017. To achieve that goal the government is trying to spur the domestic industry to continue to innovate in the face of the implementation of Industry 4.0. Minister of Industry Airlangga Hartarto revealed that innovation and changes to more efficient and effective business model are part of the implementation of industry 4.0. He believes that the industrial revolution will accelerate the significant increase of national industrial sector competitiveness (Ministry of Industry, 2017). It is estimated that the Industry 4.0 system will provide benefits to the industry, such as raising efficiency and reducing costs by around 12-15 percent (Julianto, 2017). Several national industrial sectors have entered the era of Industry 4.0, including cement, petrochemical, automotive, and food and beverage industries. In the automotive industry, the production process is already using robotic system and internet of things infrastructure. While in the food and beverage industry, Industry 4.0 technology is applied to the selection of raw materials, but for the packaging process still uses human labor. Constant speed and adaptability are natural in the implementation of Industry 4.0. Moreover, with a combination of cyberspace and physical demands, the workforce can analyze data and assess the quality and bias of data. This affects the workings of an accountant in collecting and presenting financial information and information for the needs of calculating the environmental impact of industrial operations. Issues of efficiency and sustainability need to be accommodated in a new way of the working platform.

This paper attempts to link the idea green thoughts of accounting in the new era of Industry 4.0. Deconstruction thinking is presented as a requirement to dismantle the establishment. Deconstruction thinking is presented so that researchers can see the other realities behind the visible. The term accounting of peace is presented to illustrate a critical thinking as well as a hope for how current and future accounting should become more meaningful because of the concern with others and other species (nature and the environment) to bring goodness, prosperity, and happiness. Industry 4.0 is presented as a background illustrating how the industry operates today. The term green thoughts of accounting are used to refer to various accounting terminology that directs the contribution of its attention to nature and the environment. So, the focus of this paper's discussion is how deconstruction style of thinking related with the green movement brought by the accounting of peace in industry 4.0 eras.

This paper is structured as follows. Beginning by presenting the changing role of accounting from originally emerging to the needs of war until now accounting comes to bring peace to nature and its environment. The next section presents some accounting thoughts that bring attention to the environment as well as the challenges or constraints still in it. The discussion then goes on to present the characteristics of the industry in the fourth revolutionary era, as well as how the industrial environment 4.0 can foster this green movement. The essence of deconstruction thought is presented later. Conclusions and implications are presented as a summary to emphasize what contribution can be given from the thinking of this paper.

From Accounting of War to Accounting of Peace:-

A long history tells how accounting emerged and how the current economic and political system affected the initial concept of accounting. Accounting has been a witness to the behavior of Western human war. The demands of war 
and war economy have influenced how accounting is done. A Napoleonian figure suggests that three things are needed to fight: money, money, and money (Diaconu, 2017). The orientation at that time was mere materiality and wealth. Profits and enrichment became the goal of accounting at the time. A literary review of the writings of Chwastiack and Lehman (2008) presented by (Diaconu, 2017) illustrates six circumstances that imply an accounting ignorance as well as an accounting role in favor of the rationalization of the war at the time. First, developing capitalism implies the message that human life's instinct is simply to sustain its life and destiny. So, accounting ignores the intrinsic value of the object, only the recognition of its financial value alone. Production work aims to transform nature into goods to meet the needs of life. Secondly, everything is a commodity so it is natural to have a cruel use of resources. Third, there is a mutual relationship between war and accounting. Accounting becomes violent, it does not recognize the intrinsic value of others. Accounting was born because the slave owner needed a recording of the work of their slave. Accounting information becomes important to know which slaves are productive and unproductive. Slaves whose work is unproductive will be killed or sold because they are considered as an expense of owners. Fourth, inequality is normal as the impact of economic development and globalization, and accounting also assumes the role of rationalizing it. Fifth, there will be parties who feel the negative consequences of the economy called economic sanctions. Sixth, war becomes acceptable, accounting helps to consider this aspect of the advantages and disadvantages of the condition. Accounting fails to quantify the social impacts as well as the wastage of economic resources that occur only for the sake of this war power.

The administration of the people's living needs follows the current economic system, as well as the accounting role it contains. In line with the previous description, Triyuwono, Jamhuri, Mulawarman and Prawironegoro (2016) also describe the role of accounting at that time as a recorder and the classification of property owners of the means of production during the feudalism and capitalism. Its role then developed to assist the recording and classification functions during the exchange of production and consumption goods. When the distribution of production proceeds then the accounting function leads to the calculation of the value of sales, expenses, profits, and losses. Humans as subjects as well as objects, which mutually empower. Profit is the goal of economic activity. Capital is sucked because capital is used to bring more value in addition to its own value, where the value comes from the work of others. Real oppression has occurred over the weak, power has bought the interests of many people for the benefit of the owners of capital. Nature is seen as fulfilling the needs of mankind whose value is determined by humans.

However, past circumstances cannot be brought to life now. Accounting should be present bringing new concepts and ideas that lead to the happiness of many people who measure the goal of peace and not just profit and wealth. Concern for the condition that then gave birth to the thought of a Vandana Shiva in the concept of his Earth Democracy. He called for everyone to have equality, have intrinsic value, and have the right to life (Diaconu, 2017). The development of culture and knowledge should bring people to a life of mutual good. The protection of the natural ecosystem and the species within it also becomes the emphasis of the concept of earth's democracy. Everyone should pay attention to the conservation and sustainability of the use of natural resources and species on earth. There is a relationship between social, natural and economic, all three cannot be separated to achieve prosperity for creatures on this earth.

\section{Thoughts and Problems in Green Issues:-}

When the company recognizes that the environment is a corporate asset used as a corporate strategy, then environmental management will be a major concern and the company will not seek to avoid the costs it will incur. Because in the end, the number of environmental costs incurred will provide added value and increase the value of the company. The amount of costs incurred in the social responsibility activities automatically leads to consequences on the recognition, measurement, recording, reporting, and disclosure of accounting for environmental costs.

An accounting system that presents accounts related to environmental costs is referred to as green accounting. Green accounting focuses on the accounting treatment and reporting of information on the sacrifice of the company's economic assets for the cost of social and environmental responsibility. The sacrifice of several corporate economic assets for such social and environmental purposes aims to provide added value to society and the environment (Sari, 2016). Green accounting is based on the concept of externalities, a concept that specializes in the study of the impact of economic activity that should be calculated and recorded in the financial records. The purpose of green accounting is to provide environmental cost information relevant to stakeholders.

Another term that is also often used is the environmental accounting. It also leads to environmental management, how companies achieve a balance between economic goals and environmental control objectives in business 
operations (Burrit and Christ, 2016). Environmental accounting reports provide information on costs that must be incurred by the company in anticipation of poor environmental quality or sacrifices issued by the company to conserve the environment. Hansen and Mowen (2007:671) categorize these environmental costs into four categories: prevention costs (such as quality training programs, quality planning, quality reporting, supplier evaluation and selection), appraisal costs (such as product inspection costs, product contamination testing costs) internal failure costs (such as waste recycling costs, product reworking costs) and external failure costs (such as environmental conservation costs around the plant, social costs for nearby communities). The disclosure of environmental accounting improves the environmental performance which in turn will have a positive effect on the company's financial performance. In a study with a sample of tourism sub-sector companies, hotels, and restaurants, the company's 2015 annual report has not yet fully reported its environmental costs (Homan, 2016).

The strong cause of global warming is the emission of greenhouse gases from industries (Hashim, Ramlan, Shiun et al., 2015; Plevin, Beckman, Golub et al., 2015). It identifies sources of industrial carbon emissions can be categorized into two: with on-premises carbon emissions (such as due to the burning of fuel within the building itself) and sources of carbon emissions associated with external carbon emissions. Electricity, fuel consumption, water consumption, solid waste, and wastewater are indicators of carbon performance. In the study of Hashim et al. (2015), they develop an integrated carbon accounting and mitigation framework so that carbon accounting centers and indicators can be determined, as well as emissions reduction strategies and emissions mitigation measures can be developed with due regard to cost-effectiveness. The terms carbon accounting and carbonomics have appeared in several journals some time ago (Ratnatunga, 2008; Ratnatunga and Balachandran, 2009). The emergence of this issue provides many implications for strategic management accounting areas, from business policy, human resource management, marketing and product strategy, pricing strategy, supply chain, and company performance evaluation, these aspects begin to incorporate carbon measures in decision making.

Efforts to improve the quality of corporate reporting for stakeholders are constantly being developed, both at the international regulatory level and at the technical level of the content of a company's business report. The reporting sustainability report based on the Global Reporting Initiative (GRI) is a report that measures and discloses corporate activities as a responsibility to stakeholders regarding the organization's performance in realizing sustainable development objectives. Sustainability report becomes one of the media to describe economic, environmental and social impact reporting. There are practical limitations on forms of accounting and sustainability management in their application. A principle of reflexivity that describes a process of continuous reflection on the relationship between corporate sustainability and sustainable development and the perspective of all organizational stakeholders proposed by Schneider (2014). This principle recognizes the existence of a collective learning process at the company in achieving the harmony of the three components. Such a process of learning then allows the organization to shift to a balance view between economic, ecological, and social.

In addition, there is also a more comprehensive reporting concept named Integrated Reporting (IR). IR provides a holistic reporting concept that illustrates how the company does its business processes in an integrated way (combining inputs in business processes to generate output) and creating value for the company. IR is an evolution of corporate reporting that focuses on presenting concise, strategically relevant and future-oriented reports (IIRC, 2017). The IR framework is presented in the following figure. 


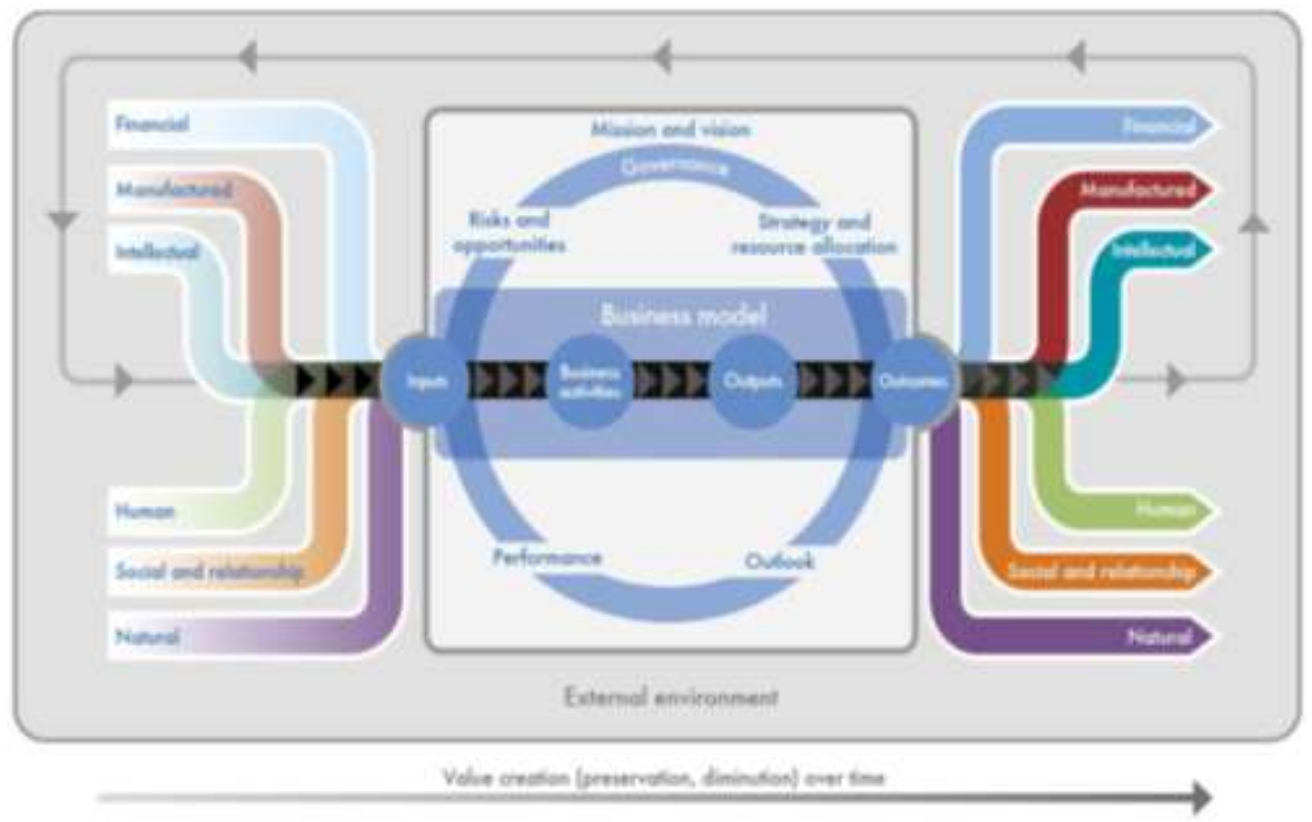

Figure 1:-Six Capital in Organization (IIRC, 2017)

The image shows how the company creates value in the business process. IR is built by six capital forces in the company of finance, manufacturing, intellectual, human, relation and social as well as natural resources. From these explanations, reaffirms the importance of information on the management of natural and social resources for the existence of companies.

In September 2015, the United Nations emphasized a new agenda for Sustainable Development which emphasizes a very clear message that social and economic development is dependent on the management of the natural environment and sustainable resources. The terminology of natural capital is also the target of policy, although it is undeniable that the use of natural capital in the monetary concept still generates polemic especially from academics. Natural capital that refers to the various components of the natural environment (minerals, animals, plants and other ecosystems) is an asset for a country that can contribute to the welfare of the country (Terama, Milligan, Aybar, Mace and Ekins, 2016). This recognition also implies the need for the ability to quantify natural capital, where this role is part of the accounting work so that then comes to the term natural capital accounting. Empirical evidence that the management of green intellectual capital is a viable investment for the company is found in research conducted by Yahya, Arshad, and Kamaludin (2017). This study was conducted to examine the relationship between green intellectual capital resources as an important predictor of corporate competitive advantage. Four categories of intellectual capital in manufacturing companies in Malaysia measured are green human capital, green innovation capital, green organization capital and green relational capital.

The Indonesian Institute of Accountants (IAI) has developed a standard of disclosure of environmental accounting under the Statement of Financial Accounting Standards. Accounting for environmental costs is set out in SFAS 1 concerning Presentation of Financial Statements, SFAS 33 concerning General Mining Accounting, SFAS 57 on Provisions, Contingent Liabilities and Asset Contractions in which transactions or events are closely related to the environment, SFAS 25 on Accounting Policies, Changes in Accounting Estimates and Error Correction, SFAS 64 on Mineral Exploration and SFAS 5 Operating Segment, which may result in financial impacts of business activities involving the company and the economic environment in which it operates. In addition, Indonesian Law No.40 year 2007 also discloses that limited liability companies engaged in business or business activities in relation to natural resources shall be obliged to carry out social and environmental responsibility (clause 77) and all limited liability companies shall provide information on the performance of social responsibility and the environment in the Annual Report of the Board of Directors at the time of the General Meeting of Shareholders (clause 66). Indonesian Law No. 40 the year 2007 is supported by Government Regulation No.47 year 2012 on the Implementation of Corporate Social Responsibility and Environment which began in 2012 has become the company's liability. 
Although the accounting standard is clear enough to regulate the environmental costs, the biggest obstacle to internalizing the externalities is the measurement of the cost and benefits that result from the activity. It is not an easy thing to measure consistently and consequently the impacts of environmental destruction on the surrounding community caused by air pollution, wastewater, leakage, crop destruction and other matters, in which these costs can sometimes not be measured accounting (Diaconu, 2017; Sari, 2016). Data quality and measurement problems in external environmental accounting lead to the comparability and reliability of the reported environmental data into something the company needs to compromise. Skepticism about the truth of the reported disclosure of environmental accounting led to the loss of data credibility (Burrit and Christ, 2016). When the quality of environmental accounting data is still low then it will have an impact in utilization for management decision-making that aims at ecoeficiency.

Agenda United Nations targets that by 2030 the goal of sustainable management and efficient utilization of natural resources can be achieved. This also implies some homework that must be done both at the policy and institutional level, especially at the technical level of its implementation. Some of the challenges faced related to effective natural capital accounting issues are presented in the figure below.

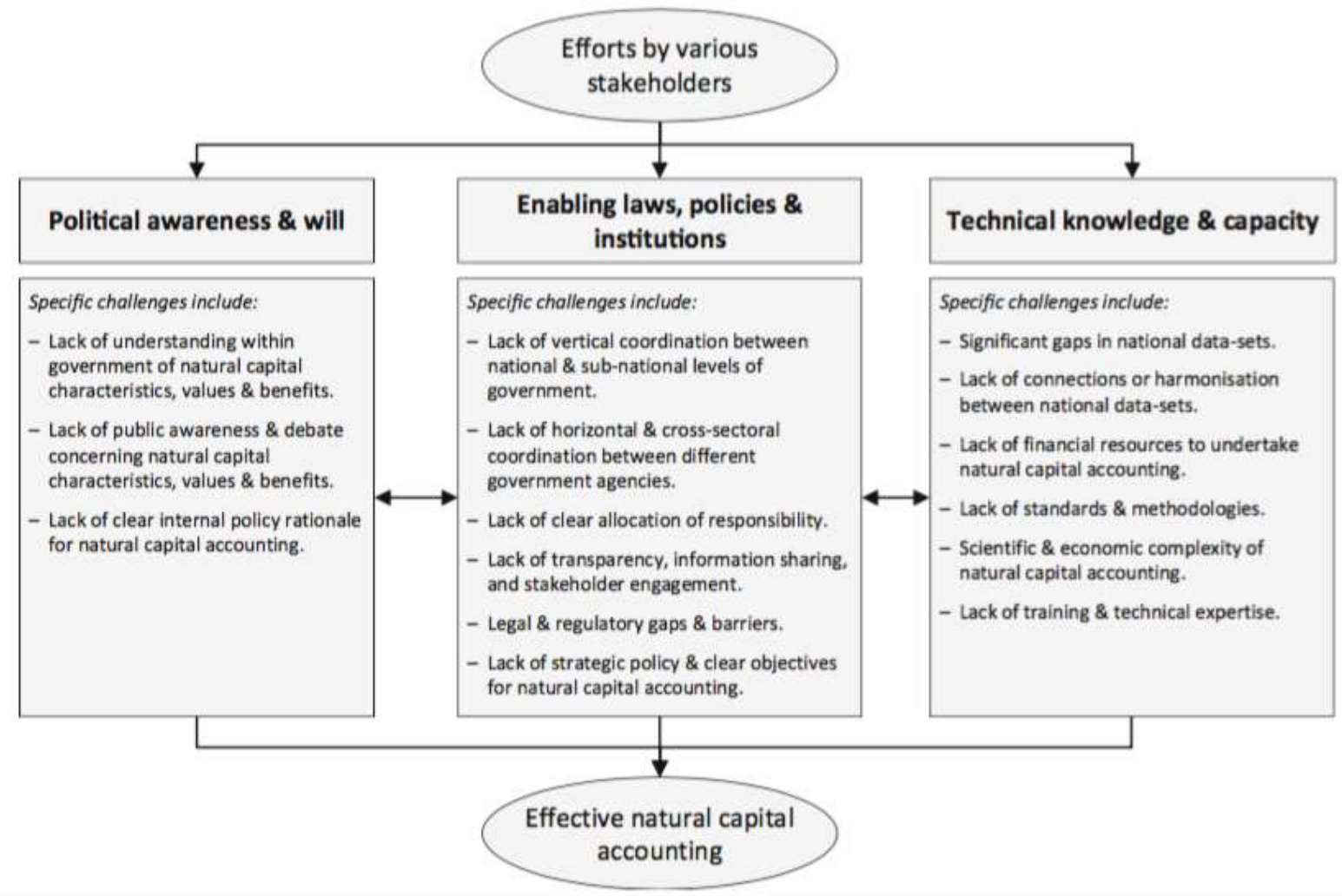

Figure 2:-Challenges for Implementation of Natural Capital Accounting (Terama et al., 2016)

The figure shows that coordination issues (vertical or horizontal), allocation, transparency, information sharing, connections, measurement standards and data collection are challenges in the application of natural capital accounting. Some of these issues lead to the need for information available to produce good quality data.

The research empirically analyzing the effect of greenhouse gas emissions on the financial performance of Indonesia's manufacturing industry in 2011 was done by Rokhmawati and Gunardi (2017). This study uses interviews with a sample of companies that are considered relevant; this is done because of the unavailability of data on greenhouse gas emissions in general. The intensity of the use and impact of $\mathrm{CO} 2$ gas is very rare even hardly ever found in the published annual report of the company, so research on such issues is mostly done by case studies through in-depth interviews to find out how this concept is practiced and affect the overall performance of the company. The results of this study indicate that the $\mathrm{CO} 2$ gas intensity of the company has a significant influence on the proxies of company performance (Return on Equity, Return on Investment, Return on Sales and Tobin's q). 
A theoretical framework of the relationship between information technology and integrated reporting reveals that the use of information technology is an efficient way to support organizations in producing better financial and nonfinancial reporting (Lamboglia, Mancini and Paolone, 2017). Information technology plays a role in helping to produce quality data, reliable, easy access, and able to produce reports that timely, relevant, consistent and useful. The researcher revealed that while various IT contributions are said to be able to support the effectiveness of the process in generating Integrated Reporting, but there is very little literature from academics and practitioners to discuss the relationship.

Accounting of peace is highly depending on the characteristics of each company in analyzing the environmental issues surrounding it. It needs strong commitment and cooperation among all departments within the company because environmental issues are part of the management control system, so this is not just the responsibility of one department. Accountants must also work with technical experts to gather information about the amount of carbon the company uses. From what has been mentioned above, issues related to accounting of peace lead to the need for better quality of information. The lack of sufficient data and infrastructure to meet these data requirements causes this sustainability concept to be so complex.

Quantification of the activities by which humans benefited from nature and its species posed a challenge in the design of this accounting of peace ideas. Is there a limit on taking mineral resources for example? how far is the activity referred to as environmental degradation? When can other species of plants and animals be sacrificed for the sake of human need? Two things that come up about this mentioned by Diaconu (2017), first, equality of rights with other species in nature needs to be considered. Second, companies need to look back at the fundamental goals of their organization, the purpose of their operations, the highest goal they want to achieve. Because the highest performance measure of the company is the happiness of human beings in it, without neglecting its relation with the natural life and environment. The accounting of peace's report should present the happiness brought by an organization, how it generates a positive energy source for society, the equivalent of profit and loss, and its future potential.

\section{Characteristics of Industry 4.0:-}

The industry has entered a new phase in technological advancement. The rise of digital technology in this industry is known as Industry 4.0. This industrial era allows each resource within the enterprise to be integrated, an evolution of advances in information technology that helps in decision-making systems, and the determination of data-driven strategies (Gamage, 2016; Rubman, Lorenz, Gerbert et al., 2015; Constantiou and Kallinikos, 2015). The nine pillars that are the strengths of the technological advances in Industry 4.0 are presented in the figure below.

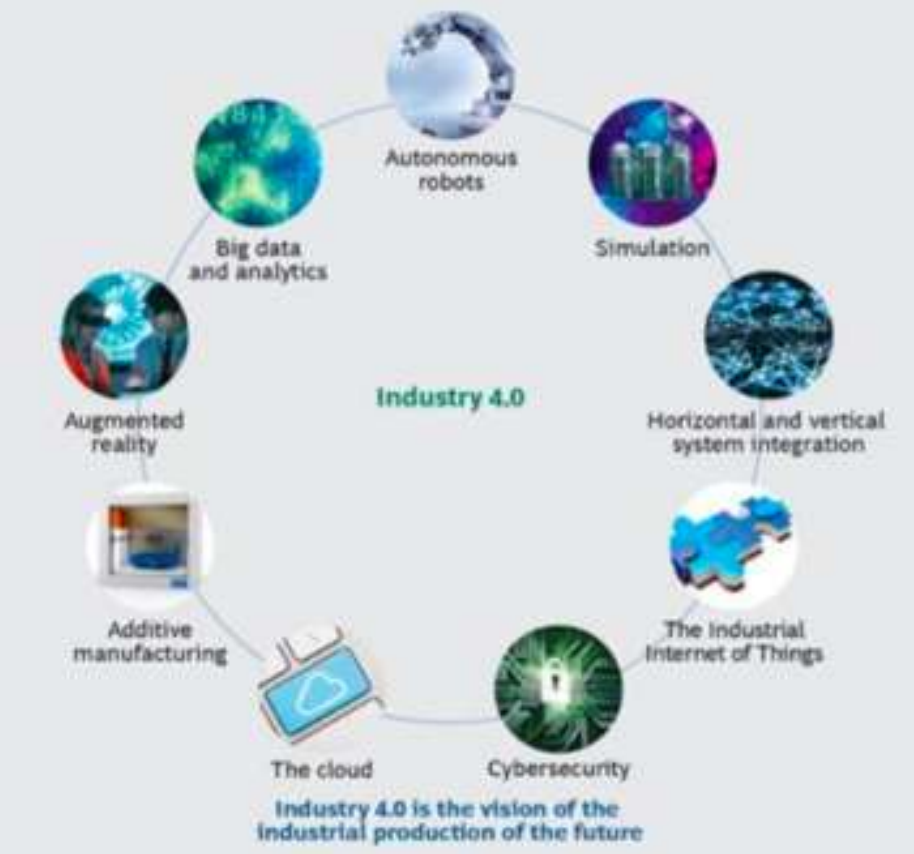

Figure 3:-Nine Pilar of Technology Advancement (Rubman et al., 2015) 
Big Data Analytics, which is a large collection of comprehensive data (volume, a variety of information and velocities) enables the industry to work more optimally and make decisions in real time. Autonomous Robots describe the human functions that are replaced by robots, this can save costs while maximizing greater capabilities in the industry. Simulations describe the circumstances in which the use of virtual models in products, materials and production processes is increasingly being used. This certainly facilitates testing and improving product quality. Horizontal and Vertical System Integration describes how companies, departments, functions, and capabilities are integrated and universally mutually automated. The Industrial Internet of Things allows more computerized devices so that analysis, control, and response can be made in real time. Cybersecurity in the Industry 4.0 is more protected from cybersecurity threats along with the increased connectivity and utilization of reliable communication protocols. The Cloud describes the use of cloud technology more and more quickly to monitor and control systems in the industry. Additive Manufacturing enables companies to produce products with excellence in construction design while maintaining high performance so that savings can be made. Augmented Reality will be increasingly used in support of real-time information services and working procedures, including virtual training.

\section{Deconstruction-Style Thinking:-}

There are many great ideas that challenge and counter at the same time "destroy" tradition that has been considered "established" when we speak of the word "critical" and "left". In the context of history this terminology leads to thoughts and social movements that seek to re-establish the conditions that are considered established (even established by dominant power and power). Some people have been misguided, if the "different" mainstream thinking is always regarded as a "left" model of thought that leads to communism (Santoso, 2015). This establishment needs to be dismantled according to critical thinkers because it may be that the establishment (including knowledge) contains a set of manipulative principles to simply maintain that establishment. Phenomenal contemporary philosophers like Karl Marx, Derrida, Foucault and other philosophers joined in the Frankfurt School, especially Herbert Marcus (nicknamed the philosopher for New Left) inspired many young thinkers thereafter. If "left-handed" thinking is given such stigma, then what about ideas in the postmodern area? They are often referred to as more than just critical thinkers.

Jacques Derrida, a French Philosopher (1930- 2004). His field of Philosophy is the Reading and Interpretation of "Text". He has a philosophical direction that seeks to oppose Logocentric. Therefore, the Philosophical mode is known as Deconstruction. Some of his famous works are: Of Grammatology (1967); Differance (1967); Margin of Philosophy (1972). Jacques Derrida with his deconstruction terminology, he invites us critically not to easily accept formal structural establishment, especially the structure of our conscious thinking, which sometimes too easily froze then claim and ultimately monopolize its own truth as the only true. This logocentric view is to be avoided. Because in such circumstances, we cannot acquire knowledge because the way we know will become too centralized or uniform. Looking at the history of civilization, the death of the creativity of the nation and society occurs when the creative world of the mind is controlled and shackled by the centralization of power and the monopoly of truth.

It is important for us to look at the meaning, mode of operation and characteristics of deconstruction (Riduwan, 2014). Deconstruction means that:

1. Change the human mind and understanding of "text" (writing, speech, thought, reality, etc.)

2. Bring out new insights that were previously unthinkable.

3. The attempt to shake up dominant and established thinking logosentrisms.

From that understanding, the mode of operation of deconstruction is:

1. Read and describe "text" (writing, speech, thought, reality, etc.) that already exist.

2. Analyze "text" to understand explicit, implicit, and hidden meanings (revealing internal inconsistencies / contradictions in "text").

3. Transform "text" and / or "text meanings" to bring new thoughts and insights.

So, two deconstruction characteristics are:

1. Do not destroy / negate existing understanding, but elevate / admit the "others" (as the new understanding).

2. The aspect that is vandalized is the claim that only a certain understanding is assumed to be true, whereas other understandings are considered wrong. 


\section{Deconstruction for Green Research in Accounting (in Industry 4.0 age):-}

Philosophy (thinking) Derrida's has meaning that: a). The symbol (sign) in the language cannot represent reality as it is; b). The "text" truth is plural, not singular; c) What is considered true is a mistake, because truth is always present pending, d) What is assumed to be in the real world, is only an illusion / perception that is inside the human mind (Riduwan, 2014). Therefore, what needs to be further analyzed is whether green research has presented the noble purpose of an ideal study for the welfare of the universe? do the various forms of terminology and the idea of green movement reporting have touched the substantive region and not merely to show something symbolic? Then whether the industry 4.0 provides an opportunity or maybe a challenge for the two previous goals?

Considering the problems faced by the green movement for an accounting in the previous discussion. Some problems come from poor data quality (timeliness, accuracy, reliability, and comparability of data on accounting reports); what is measured, how the report containing the environmental information is measured and reported; as well as the need for improving the credibility of the data (Burrit and Christ, 2016). These problems are likely to be reduced in the current industry 4.0 based on big data, digitization and integration. But again, this issue is largely rooted in the substance of reporting from the green movement, not merely the success of generating reports.

Accounting serves as a source of data, information processing, measurement, analysis, and reporting, therefore accountants will play their role in Industry 4.0 based on big data and data analysis. There are at least three areas of opportunity that accountants can gain in this new era related to valuation of data, decision-making use, and BigData's use in considering risk management (Gamage, 2016). The acquisition and calculation of the data required to measure environmental costs have the potential to be more accessible, more detailed in the presentation of the information, more assured of its data quality so that it can be used for various types of decision making and management control objectives (Burrit and Christ, 2016).

The Industry 4.0 will enable more real-time data analysis so as to predict failure more precisely, facilitate data collection, analyze cross-border data, enable efficiency in the process of producing good quality products, so that cost reduction can be achieved. This proved to increase productivity, earnings growth, facilitate employment and increase investment opportunities (Rubman et al., 2015; Burrit and Christ, 2016). Poor quality data on environmental impacts and operational costs will not be found in Industry 4.0, a work based on automated decision making by intelligence engines will make everything faster detectable, including manufacturing errors or failures that have environmental consequences. A digital-based manufacturing environment will improve the quality of environmental accounting data (externalities) thereby increasing productivity. Energy costs used can be monitored automatically so that the source of energy supply can automatically switch automatically to low carbon emissions or even none in the manufacturing process (Burrit and Christ, 2016).

Lamboglia et al. (2017) propose that IT resources must fulfill three functions in order that IT use can effectively support the company's Integrated Reporting. First, automation (when IT replaces the function of human activity); secondly, information (relevant and timely data which capable to describing real situations in the company so that each task can be performed efficiently and effectively), and third, transformation (resources that help the company restructure its internal potential to produce better output). The Industry 4.0 that has advanced technology has provided a capable platform to use with maximum benefits for the provision of comprehensive integrated reports.

Changes in a corporate system require a thorough approach. The three approaches that the institution must consider in the process of change are the political and economic level, the organizational field aspect and the organizational aspects (Alsharari, Dixon and Youssef, 2015). Understanding these three aspects helps management determine the proper systems and practices in the process of management accounting changes that exist within the organization. The green movement is a long journey, along with the increasing awareness of many parties on environmental issues in running a business, as the competitive business competition where competitive advantage is also built from synergistic and harmonious business practices between people, the planet, and profit.

A study that discusses factors that might influence managers' tendency to use information obtained through Big Data and Analytic techniques in support of decision making, the results suggest that Big Data and Analytic initiatives may be more successful when they are used to support strategic management than used at the operational level (Castellano, Presti and Gobbo, 2017). Organizations are still in organizational learning mode at the operational level. They found that management information systems should be coherently adjusted to a specific set of decisions, enabling organizational learning strategies, as well as the use of Big Data and Analytic. In addition, individual 
characteristics of managers, especially years of experience and confidence in using the information to support decision-making can influence a manager's tendency to rely on Big Data and Analytic. Environmental issues are a strategic issue so that the use of information available in the database will help to formulate the strategic plan for the company. Industry 4.0 has changed how people work. The existence of a database pool that can be accessed by all parties within the company allows decision making by humans to be more informative. In relation to these environmental issues, accountants must also be able to work with interdisciplinary strategic teams. They will also be in contact with environmental lawyers as well as engineers to jointly access and use real-time environmental data and collaborate to take eco-efficiency measures (Burrit and Christ, 2016).

If we look at what has been disclosed above, then it seems that industry 4.0 provides an opportunity for improving the quality of reporting from this green movement. We need to look at the following reviews. An example I took from research on CSR. I want to show how we should be critical with some of the issues that are present in this green movement. A study aimed at investigating the use of three forms of Corporate Social Responsibility (CSR) reporting practices: the use of stand-alone reports, assurance of CSR information and reporting guidelines (with GRI framework) shows the result that the quality of information disclosed in individual reports is no different from the quality of information disclosure of CSR reported in the annual report, although individual reports used by the company contain more information (Michelon, Pilonato, and Ricceri, 2015). CSR reporting is criticized for its lack of relevance and credibility, and its failure to impact sustainability development. This research seeks to contribute to this criticism by offering a new understanding of the complexity and quality of CSR disclosure and their relationship with the adoption of the three forms of CSR practice above. This certainly raises a big question mark, so far the company disclose its CSR for the sole purpose of symbolic or indeed very concerned with the substantive purpose of the quality of information from the disclosure. Under a substantive approach to corporate legitimacy, real change in corporate action is used to harmonize organizational strategies and processes against social norms. Meanwhile, under a symbolic approach, practices appear to positively influence stakeholder perceptions, directing stakeholders wrongly believing that the company is committed to social expectations.

Accountants need to understand this phenomenon, and only by way of deconstruction thinking then the accountant can contribute. Any text contained in the environmental disclosure about profit, planet and people must also be substantive, and this is the way of thinking of the deconstruction. Relevance of Derrida philosophy with green research in accounting as follows (Riduwan, 2014):

1. It is recognized that representation of economic reality through symbols (words and numbers) is a problem in accounting and financial reporting. This also occurs in the scope of green research in accounting.

2. The change of SAK from a rule-based standard to a principle-based standard is evidence that the truth of the "text" is plural, not singular (Derrida's thinking of the grand narration). The question then is the truth of who? There are various stakeholders behind this.

3. Ongoing SAK (IFRS) revisions, as well as the ever-evolving thoughts in this green movement are evidence that accounting information considered true in the past is in fact misinformation. (Derrida's thinking of the truth).

4. Accounting policies and estimates often do not represent the real world, but only as concepts and assumptions. (Derrida thinking about metaphysics of presence).

So, it can be concluded that Derrida's philosophy (thought) is highly relevant and can be utilized in green research in accounting. Derrida's philosophy (thought) in accounting research can be positioned as: the basis of argument conducted research; tool of analysis; and justification of the research results. The Green research in accounting must make a real contribution to the universal welfare, through its thoughts of deconstructing text and reality.

Three issues discussed in this paper are the environmental and natural-focused accounting, deconstruction thinking and Industry 4.0 as a background, providing theoretical, practical and policy implications. Both issues provide insight into new scholarship as well as further research opportunities. Areas of management accounting, tax and auditing are some areas of accounting related to environmental issues. Environmental management accounting, business taxes and natural resource utilization, supply chain management topics and environmental audits are just a few of the issues. A new round of technology-based industry also implies a message for educators to start incorporating data-driven analytical skills as their graduate qualifications both in curriculum design, field experience and educational opportunities with industry. The role of management accountants, forensic accountants, tax accountants and auditors are some of the areas that share the immediate implications of this Big Data era. The focus of a current professional and financial accountant is not only on accounting information systems but also on information storage, management, and analysis (Gamage, 2016). 
Green movement in accounting is not merely the responsibility of the industry; academics and educational institutions can also play its role. Creating a culture that pays attention to social and environmental aspects is part of educating the community of these educational institutions (students, faculty, and staff) to have ethical principles in carrying out business practices. However, the students will be the actors in the industry, and they are not sufficiently equipped with technical knowledge in accounting but also need to have awareness and sensitivity to environmental issues around the industry. Therefore, this green accounting can be part of a university's social responsibility (Putri, 2016).

Practitioners including accounting professions are expected to become providers, facilitators, and analysts in realizing informative reporting on the environment in decision making. Similarly, for corporate management, infrastructure investment for the Industry 4.0 that spends considerable value will be comparable if the company's management can maximize its benefits including in gathering information and using it in environmental reporting. By understanding the benefits to be gained from Industry 4.0 then management can also direct the company's strategic plan to the goal of eco-efficiency through the acquisition of accurate and timely data. The Government of Indonesia has a strong commitment to welcome this Industry 4.0. Minister of Industry Airlangga Hartarto revealed that the utilization of digital technology can boost productivity and competitiveness. For example, through industrial automation technology can be utilized to optimize production schedules based on suppliers, customers, machine availability and overcome the cost constraints. The Government plays a role in creating a regulation capable of supporting green business practices amid the challenges as well as the potential that can be gained from Industry 4.0. Socialization and training to prepare informative accounting reporting for accountants and business practitioners can be done by accounting professional institutions. Sweet promise over the ease of industry 4.0 also still must be addressed wisely. The accountant must remain skeptical of every circumstance in their social reality.

\section{Conclusion:-}

The goal of eco-efficiency is now no longer an option for the company. Business practices that promote green business philosophy demand that management is also "green" so of course the need for information that can provide it becomes one of the company's strategic priorities. The accounting function seeks to accommodate those needs through its various thought contributions aimed at generating relevant information related to the consequences of the company's business practices on the environment. Accounting ideas leading to concern for other species including animals, plants, and ecosystems, and striving to achieve balance, well-being, and happiness for the universe are used to refer to the term accounting of peace. Accounting ideally capable to achieve the highest performance goals in an organization. The fourth industrial revolution referred to as Industry 4.0, provides the potential for encouraging the presentation of environmental accounting reporting more real-time and accurate. Some of the obstacles related to the limited availability of environmental data, poor quality of environmental data, difficulties in collecting environmental data, limitations in the use of cross-departmental environmental data and some other things can be minimized by the benefits that Industry 4.0 can provide. Strategic decision-making that also incorporates aspects of the environment can be achieved more timely and supported by a strong database. Industry 4.0 provides an initiation for better implementation of the green movement. The application of the Derrida Deconstruction concept in green research in accounting is expected: a) paving the way to support the plurality of thought in the development of accounting theory and practice; b) spur the thinkers to participate in the development of accounting practices according to what they need.

The issues discussed in this paper also imply both theoretical, practical and policy implications. There is still a wide range of research opportunities for the relationship between all the concepts that bring this accounting of peace philosophy, especially if it is linked to today's industry-based digital, internet and big data. Empirical evidence is still needed in this regard. Practitioners and management companies also need to prepare resources both in terms of quality of human resources are qualified both in terms of database and analysis and knowledge of environmental accounting. Likewise, the regulation and conducive business climate through regulations aimed at mutual prosperity. 


\section{References:-}

1. Alsharari, N. M., Doxon, R., and Youssef, M. A. E. (2015). Management Accounting Change: Critical Review and New Contextual Framework. Journal of Accounting and Change, Vol. 11(4), 476-502.

2. Burrit, R., and Christ, K. (2016). Industry 4.0 and Environmental Accounting: A New Revolution?. Journal of Sustainability and Social Responsibility, Vol. 1, 23-38.

3. Castellano, N., Presti, C., Gobbo, R. (2017). Employing Big Data and Analytics in Decision Making: Factors Affecting Managers' Trustworthiness. The European Conference on Information Systems Management, September, 37-46.

4. Constantiou, I and Kallinikos, J. (2015). New Game, New Rules: Big Data and the Changing Context of Strategy. Journal of Information Technology, Vol. 30(1), 44-57.

5. Diaonu, Paul. (2017). From the Accounting of War to the Accounting of Peace: Putting Bricks for a New Environmental Accounting: A Critical Analysis. Accounting and Management Information Systems, Vol. 16(1), 107-131.

6. Gamage, P. (2016). Big Data: Are Accounting Educators Ready?. Accounting and Management Information Systems, Vol. 15(3), 588-604.

7. Hansen, D. R. and Mowen, M. M. 2007. Managerial Accounting. $8^{\text {th }}$ Edition, Thomson South-Western, USA.

8. Hashim, H., Ramlan, M. R., Shiun, L. J, Siong, H. C., Kamyad, H., Majid, M. Z., Lee, C. T. (2015). An Integrated Carbon Accounting and Mitigation Framework for Greening the Industry. Energy Procedia, 75, 2993-2998.

9. Homan, H. S. (2016). Environmental Accounting Roles in Improving the Environmental Performance and Financial Performance of the Company. South East Asia Journal of Contemporary Business, Economics and Law, Vol. 11(1), 9-15.

10. IIRC. (2017). Integrated Reporting: The Tool for Better Reporting. Retrieved from: https://integratedreporting.org

11. Julianto, P.A. (2017). Ini Strategi Indonesia Masuk Revolusi Industri 4.0. Retrieved from: http://bisniskeuangan.kompas.com/read/2017/05/14/160000326/ini.strategi.indonesia.masuk.revolusi.industri.4.0.

12. Lamboglia, R., Mancini, D and Paolone, F. (2017). The Relationship between Information Technology and Integrated Reporting: A Theoretical Framework. The European Conference on Information Systems Management, September, 148-156.

13. Michelon, G., Pilonato, S and Ricceri, F. (2015). CSR Reporting Practices and the Quality of Disclosure: An Empirical Analysis, 1-20.

14. Ministry of Industry. Siaran pers, Industri 4. (2017) Solusi Peningkatan Daya Saing Indonesia. Retrieved from: http://kemenperin.go.id/artikel/17432/Industri-4.0-Solusi-Peningkatan-Daya-Saing-Indonesia.

15. Plevin, R. J., Beckman, J., Golub, A. A., Witcover, J., O’Hare, M. (2015). Carbon Accounting and Economic Model Uncertainty of Emissions from Biofuels-Induced Land Use Change. Environmental Science and Technology, Vol. 49(5), 145

16. Putri, D. P. (2016). Green Accounting as Part of University Social Responsibility: A Literature Review. International Conference on Education, 215-223.

17. Ratnatunga, J. (2008). Carbonomics: Strategic Management Accounting Issues. Journal of Applied Management Accounting Research, Vol. 6(1), 1-10.

18. Ratnatunga, J and Balachandran, K. (2009). Carbon Business Accounting: The Impact of Global Warming on the Cost and Management Accounting Profession. Journal of Accounting, Auditing and Finance, April, 333-355.

19. Riduwan, A. (2014). Metode Dekonstruksi Derrida dalam Akuntansi. Makalah Accounting Research Series 6. Universitas Brawijaya.

20. Rokhmawati, A. and Gunardi, A. (2017). Is Going Green Good for Profit? Empirical Evidence from Listed Manufacturing Firms in Indonesia. International Journal of Energy Economics and Policy, Vol. 7(4), 181-192.

21. Rubman, M., Lorenz, M., Gerbert, P., Waldner, M., Justus, J., Engel, P., Harnisch, M. (2015). Industry 4.0: The Future of Productivity and Growth in Manufacturing Industries. Retrieved from: http://www.inovasyon.org/pdf/bcg.perspectives_Industry.4.0_2015.pdf

22. Sari, M. R. (2016). Dampak Green Accounting terhadap Kinerja Keuangan. SwaOnline. Retrieved from: https://swa.co.id/swa/my-article/dampak-green-accounting-terhadap-kinerja-keuangan.

23. Schneider, A. (2014). Reflexivity in Sustainability Accounting and Management: Transcending the Economic Focus of Corporate Sustainability. Journal Business Ethics, March, 1-13.

24. Terama, E., Milligan, B., Aybar, R. J., Mace, G. M., Ekins, P. (2016). Accounting for the Environment as an Economic Asset: Global Progress and Realizing the 2030 Agenda for Sustainable Development. Sustainable Science, Vol. 11, 945-950.

25. Triyuwono, I., Jamhuri, A., Mulawarman, A. D., Prawironegoro, D. (2016). Filsafat Ilmu Akuntansi: Berpikir Kontemplatif, Holistik, Intuitif, Imajinatif, Kreatif, Rasional dan Radikal dalam Akuntansi. Publisher Mitra Wacana Media, Indonesia.

26. Yahya, N. M., Arshad, R., and Kamaludin, A. (2017). Green Intellectual Capital as Drivers of Firms' Competitive Advantage. International Conference on Intellectual Capital and Knowledge Management and Organizational Learning, November, 327-335. 